\title{
28 Research Square \\ The Attitudes and Motivation of University Learners Towards Learning English
}

Mohammed Hajeb ( $\nabla$ mohammedhajeb120@gmail.com )

Dr. Babasaheb Ambedkar Marathwada University https://orcid.org/0000-0001-8836-5677

Mohammed Masoud

Aligarh Muslim University

Bedoor Sharaf Al-Deen

Aligarh Muslim University

Original article

Keywords: Attitude, Motivation, Learning English, Foreign language, Second language.

Posted Date: July 27th, 2021

DOI: https://doi.org/10.21203/rs.3.rs-738284/v1

License: (1) This work is licensed under a Creative Commons Attribution 4.0 International License.

Read Full License 


\section{Abstract}

This study examines the Yemeni students' attitudes and motivation towards learning English. It tries to find out the types of motivation the subjects have towards learning English. Two types of motivations were investigated in this research, instrumental motivation that refers to the utilitarian and academic causes, and integrative motivation, which refers to the social and cultural causes. Moreover, the current survey sheds some light on the students' anxiety about the English language and their attitude towards learning English and using it in India. The quantitative data were collected using a questionnaire administered to 107 students. The data analyzed using the Statistical Package for the Social Sciences (SPSS) version 20. The results revealed that Yemeni students in India have a high positive attitude towards learning English. Moreover, they are instrumentally and integratively motivated to learn English. Their attitude towards the anxiety of English, learning English, and using it in India was moderate. The results also showed a significant difference in the students' attitude towards learning English, where the postgraduate students have a higher positive attitude than undergraduates. According to the gender, the results revealed no significant difference between males and females regarding the attitude and motivation towards learning English. The present survey recommended teaching the English language intensively in Yemen, whether in schools or universities. The English language anxiety has to be manipulated by teachers using the courses that enhance the students' confidence in using English.

\section{Introduction}

English is used in Yemen as a foreign language. It is taught as one subject in public schools from grade 7 to 12. In university education, it is taught as one subject in one level during two semesters. In Yemen there are many institutes where students can improve their English skills. The status of English in India is different from its status in Yemen. English in India is used as a second language. It is used along with the Hindi language as an official language in all Indian states. It is the primary medium of instruction in higher education all over India. Therefore, Yemeni students come to India for educational purposes. Some of them are at the undergraduate level and others at the postgraduate level. Yemeni students are not gathered in one area; they spread all over India and study in different universities. Accordingly, the present study aims to examine the Yemeni students' attitudes towards learning English, the students' anxiety of English and their attitudes towards learning English and using it in India. Furthermore, the current survey tries to find out the types of motivation Yemeni students have towards learning English. This study also determines the statistical significant differences in the students' attitudes and motivation according to their education level and age.

Based on the aims, the current survey focuses on two factors: attitude and motivation. According to Gardener (1985), "attitude is an evaluative reaction to some referent or attitude object, inferred based on the individual's beliefs or opinions about the referent" (p.9). Gardener (1985), Briñol \& Petty (2012), and Bohner \& Dickel (2010) stated that attitude refers to the evaluation the individuals have towards things or objects. There are three components of attitude, a cognitive component, an affective component and a conative component. A cognitive component means the thoughts and beliefs towards an object. The 
affective component refers to the individual's feelings and emotions. The conative component relates to one's actions with behavioral intention (Bartram 2010, p. 35). Attitude is different from one another; people have not the same type of attitude. The attitudes of some individuals help them achieve goals or overcome obstacles. In contrast, other people have frustrating attitudes, stopping them from dealing with challenges and accomplishing their objectives (Harrell, 2000, p.14). Motivation is the second factor this study focuses on. According to Gardener "Motivation refers to the combination of effort plus desire to achieve the goal of learning the language plus favourable attitudes toward learning the language." (Gardner, 1985, p.10). There are two main types of motivation towards learning the second or foreign language: Integrative and Instrumental motivation. Instrumental motivation refers to educational or utilitarian purposes. Students learn the language to get proficiency in a language for utilitarian reasons, get a good job, get a good salary, and use it for education. Integrative motivation, on the other hand, refers to social and cultural purposes. Students learn the language to understand the cultures and traditions of the native speakers, communicate with foreigners, integrate with the community that speaks the language, etc. (Gardner, 1985; Krashen, 1981). Many studies have been conducted on the attitudes and motivation towards learning English (Al-Tamimi and Shuib, 2009; Al-Sohbani, 2015; Pineda, 2011; Alkaabi, 2016; Qashoa, 2006; Almamun et al., 2012; Al Noursi, 2013; Köseoğlu 2013; Singh 2014; Segran 2015; Holbah 2015; Al-Anisi 2016). The previous studies were of two types. Some studies have been carried out on the students' motivation, identifying the types of motivation that students have towards learning English. The other type of studies investigated the students' attitude towards learning English, identifying whether students have a positive or negative attitude towards learning English.

The current research is similar to the previous studies in that, it concentrates on the two types of motivation (i.e., instrumental and integrative motivation). It tries to find out whether students have the same level of motivation, or there is one type of motivation that is higher than the other. On the other hand, this study is different from the previous studies, where it sheds light on the students' English anxiety, and the attitude towards learning English and using it in India. It tries to determine whether Yemeni students have positive or negative attitudes, and explore the reasons behind the individual's attitudes. Moreover, the current research is unique where there are no previous studies that have been conducted on the Yemeni students' attitudes and motivation in India towards learning English.

\section{Methodology}

\section{The Research Questions}

1. Do Yemeni students in India have positive or negative attitudes towards learning English?

2. Do Yemeni students in India have integrative or instrumental motivation towards learning English?

3. To what extent are the students anxious about the English language?

4. What are the attitudes of Yemeni students towards learning English and practicing it in India? 5. Are there any differences in the attitudes of students according to their gender and education level? 
6. Are there any differences among the students' motivation according to their gender and educational level?

7. Are there any differences in the students' anxiety of English according to their gender and education level?

8. Are there any differences in the attitudes of Yemeni students towards learning English and practicing it in India?

\section{Data collection}

The data was collected quantitatively by the mean of a questionnaire. The questionnaire was adapted by (Al-Khasawneh \& Al-Omari, 2015; Al-Zubeiry, 2012; and Al-Tamimi \& Shuib, 2009) based on Gardner's (1985) Attitude/Motivation Test Battery (AMTB). The researcher composed only two items that examine the students' attitude towards learning English and practicing it in India. The questionnaire was divided into four sections. The first section was detected for the demographical background of the subjects who participated in this study, and the other three sections consist of 22 items devoted to examining the Yemeni students' orientations towards learning English.

The second section was devoted to examining the students' attitudes towards learning English. Five items were meant to examine the subjects' attitudes to learning English (e.g., "I like learning English" and "When I hear someone speaks English well, I wish I could speak like him."). The five items of the second section try to determine whether the subjects have a positive or negative attitude towards learning English. There are four items in the second section: two items devoted to examining the students' English anxiety and two items for examining the students' attitudes towards learning English and using it in India.

The third section studies the students' instrumental motivation. This section focuses on the utilitarian and academic reasons that cause students to learn English. It is meant to be examined by seven items (e.g., "Learning English is important for me because it helps me get a suitable job in the future.", and "Learning English is essential for me because it helps me search for information and English materials on the Internet.").

The fourth section investigates the students' integrative motivation to learn English; it concentrates on the social and cultural reasons that cause them to learn English. The $4^{\text {th }}$ section was meant to be examined by six items (e.g., "Learning English helps me understand the cultures and traditions of English native speakers." and "Learning English helps me make friends easily with foreigners.").

The five-point Likert scale was used with all items of the questionnaire that is composed of closed-ended questions. The Likert scale is more reliable and can be constructed in a short period (Kothari, 2004). Thus, the five-point Likert scale is the best instrument for this survey. The values of the five-point Likert scale were arranged as follows: 
૧ Agree 4

口 Neutral $\quad 3$

๑ Disagree $\quad 2$

๑ Strongly Disagree $\quad 1$

\section{Participants}

The field of this study was the Yemeni students in India. Some Yemeni students come to India to learn English and to pursue their university education. They are spread all over India, and there is no specific census for them in India. The non-probability sample technique was utilized for sample selection. The sample selected was 107 students distributed as follows:

Table 1. The Distribution of Participants

\begin{tabular}{|lcclcc|}
\hline Education level & \multicolumn{5}{l|}{ Gender } \\
\hline Postgraduate & 74 & $69.2 \%$ & Male & 92 & $86 \%$ \\
\hline Undergraduate & 33 & 30.8 & Female & 15 & $14 \%$ \\
\hline
\end{tabular}

\section{Validity and Reliability}

The questionnaire has been adapted depending on some earlier studies as mentioned above. After designing the first version of the questionnaire, it was sent to some experts to revise it and give their comments and remarks regarding the validity of the instrument. As Arabic is the mother tongue of the subjects, the questionnaire was translated from English to Arabic to be clear and to eliminate the ambiguity that may affect the instrument's validity. The questionnaire was carried out online for the piloting study, and 22 students answered it. Based on the piloting study, some modifications were made to the questionnaire. Then, Cronbach's alpha was used for measuring the reliability of the questionnaire. The results revealed that the questionnaire is highly reliable, as shown in table (2). Eventually, the last version of the questionnaire was distributed online for the main subjects to reach many different states all over India.

\section{Table 2. The Reliability of the Questionnaire.}




\begin{tabular}{|lll|}
\hline Dimensions & No of Items & Reliability \\
\hline Positive attitude & 5 & 0.882 \\
\hline Anxiety of English & 2 & 0.585 \\
\hline Learn English and use it in India & 2 & 0.701 \\
& & \\
\hline Instrumental motivation & 7 & 0.897 \\
\hline Integrative motivation & & \\
\hline All questionnaire items & 6 & 0.896 \\
\hline
\end{tabular}

\section{Data analysis tools}

The data were analyzed using the Statistical Package for the Social Sciences (SPSS version 20). Two tools were used for statistical analysis: descriptive and inferential analysis. The descriptive analysis measures used in this study were mean, standard deviation and frequency distribution. The Independent t-test was used to measure the significant differences between the subjects according to their gender and level of education.

\section{Results And Discussion}

As mentioned above, the analysis of this data was used by descriptive and inferential statistical analysis tests. The data analysis was divided into two sections: the first section is specified for descriptive analysis and the second section is for inferential analysis.

\section{Descriptive Analysis}

The descriptive analysis is meant to address the following questions

1. Do Yemeni students in India have positive or negative attitudes towards learning English?

2. Do Yemeni students in India have integrative or instrumental motivation towards learning English?

3. To what extent are the students anxious about the English language?

4. What are the attitudes of Yemeni students towards learning English and practicing it in India?

\section{Attitude towards Learning English}

Table 3, demonstrates the Yemeni students' attitudes towards learning English. The subjects' attitude was meant to be examined by five positively worded items. The results showed that all items elicited the 
response of strong agreement. The highest average was given to item 1, "I like learning English." with a mean of 4.85 and standard deviation of 0.79 , followed by items 2 and 3 with a mean score of 4.69 and 4.68 , respectively. The last two items were designed to examine the students' attitude towards teaching English in Yemen. As stated early, English in Yemen is taught in public schools from grade 7 to 12, and in university education, it is taught in level one only as one compulsory subject for two semesters. The results revealed that the two items awarded a strong agreement. Item 4, "English should be a compulsory subject in Yemeni primary schools" got a strong agreement with a mean of 4.52 and standard deviation of 0.85 , followed by item 5 "English should be a compulsory subject in Yemeni universities from level 1-4" with a mean of 4.42 and standard deviation of 0.66 . Students revealed a favorable attitude towards teaching English widely in Yemeni schools and universities. The total average of students' attitudes is 4.58 , with standard deviation of 1.00. The mean score of 4.58 indicates the response of strong agreement. Accordingly, Yemeni students in India have a high positive attitude towards learning English. These results are similar to (Al-Tamimi \& Shuib, 2009; Chalak \& Kassaian, 2010; Pineda, 2011; Almamun et al., 2012; Al-Zubeiry, 2012; Al Noursi, 2013; Singh, 2014; Al-Sohbani, 2015; Al-Anisi, 2016; Alkaabi, 2016; Isti \& Istikharoh, 2019; Astrid et al., 2020). They found that students have a positive attitude towards learning English. On the other hand, this study contradicts Abidin et al. (2012) where they found that students have a negative attitude towards learning English.

Table 3. The Descriptive Analysis of Students' Attitude.

\begin{tabular}{|c|c|c|c|c|c|c|c|c|c|c|c|c|}
\hline \multirow[t]{2}{*}{ Statement } & \multicolumn{2}{|l|}{ SA } & \multicolumn{2}{|l|}{ A } & \multicolumn{2}{|c|}{$\mathrm{N}$} & \multicolumn{2}{|c|}{ SD } & \multicolumn{2}{|l|}{ D } & \multirow[t]{2}{*}{ Mean } & \multirow[t]{2}{*}{ Std. } \\
\hline & $F$ & $\%$ & $\mathrm{~F}$ & $\%$ & $\mathrm{~F}$ & $\%$ & $\mathrm{~F}$ & $\%$ & $\mathrm{~F}$ & $\%$ & & \\
\hline $\begin{array}{l}\text { 1. I like learning } \\
\text { English. }\end{array}$ & 76 & 71 & 22 & 20.6 & 5 & 4.7 & 3 & 2.8 & 1 & 0.9 & 4.85 & 0.79 \\
\hline $\begin{array}{l}\text { 2. When I hear } \\
\text { someone speaks } \\
\text { English well, I wish I } \\
\text { could speak like him. }\end{array}$ & 88 & 82.2 & 12 & 11.2 & 2 & 1.9 & 3 & 2.8 & 2 & 1.9 & 4.69 & 0.80 \\
\hline $\begin{array}{l}\text { 3. Learning English is } \\
\text { very important because } \\
\text { it is the language of } \\
\text { international } \\
\text { communication. }\end{array}$ & 85 & 79.4 & 15 & 14.0 & 3 & 2.8 & 3 & 2.8 & 1 & 0.9 & 4.68 & 0.74 \\
\hline $\begin{array}{l}\text { 4. English should be a } \\
\text { compulsory subject in } \\
\text { Yemeni primary } \\
\text { schools. }\end{array}$ & 71 & 66.4 & 28 & 26.2 & 4 & 3.7 & 1 & 0.9 & 3 & 2.8 & 4.52 & 0.85 \\
\hline $\begin{array}{l}\text { 5. English should be a } \\
\text { compulsory subject in } \\
\text { Yemeni universities } \\
\text { from level } 1-4 \text {. }\end{array}$ & 72 & 67.3 & 19 & 17.8 & 9 & 8.4 & 3 & 2.8 & 4 & 3.7 & 4.42 & 1.0 \\
\hline Total mean score & & & & & & & & & & & 4.58 & 0.66 \\
\hline
\end{tabular}


$\mathrm{SA}=$ Strongly Agree; $\mathrm{A}=$ Agree; $\mathrm{N}=$ Neutral; $\mathrm{D}=$ Disagree; $\mathrm{SD}=$ Strongly Disagree; $\mathrm{Std}=$ Standard Deviation; $\mathrm{F}=$ Frequency; \%= Percent.

\section{Language anxiety}

As illustrated in Table 4, the results show that the subjects have anxious about using English. The two statements got the response of agreement. The higher average was given to item 7, "It bothers me trying to understand the more complex aspects of English" with mean score of 3.42 and standard deviation of 1.07 , followed by item 6, "I feel anxious if someone asks me something in English" with mean score of 3.04 and standard deviation of 1.25. The total mean score for the anxiety of using English is 3.23, and this indicates the response of neutral towards the anxiety of using English. According to Gardener (2006), language anxiety depends on the learners' level of experience. Thus, learners who have a poor experience in any language will have anxiety about that language. He also argued that inadequate skills cause feelings of language anxiety. Based on these results and what Gardener (2006) said, participants reported their English language anxiety, which indicates that students may have inadequate English language skills. In this study, the results revealed that the level of anxiety of English is moderate. So, this research contradicts Alshamy (2012). In his study on the attitude of EFL learners towards English, he found that the level of anxiety among participants was high. Based on the findings of this section, The English teachers should manipulate the students' English language anxiety through the courses that enhance the student's confidence when using the English language. The anxiety of English may refer to some linguistic challenges that need to be dealt with by the English teachers.

\section{Table 4. The Descriptive Analysis of Anxiety of English.}

\begin{tabular}{|c|c|c|c|c|c|c|c|c|c|c|c|c|}
\hline \multirow[t]{2}{*}{ Statement } & \multicolumn{2}{|l|}{ SA } & \multicolumn{2}{|l|}{ A } & \multicolumn{2}{|l|}{$\mathrm{N}$} & \multicolumn{2}{|l|}{ D } & \multicolumn{2}{|c|}{ SD } & \multirow[t]{2}{*}{ Mean } & \multirow[t]{2}{*}{ Std } \\
\hline & $F$ & $\%$ & $\mathrm{~F}$ & $\%$ & $F$ & $\%$ & $\mathrm{~F}$ & $\%$ & $F$ & $\%$ & & \\
\hline $\begin{array}{l}\text { 6. I feel anxious } \\
\text { if someone } \\
\text { asks me } \\
\text { something in } \\
\text { English. }\end{array}$ & 18 & 16.8 & 18 & 16.8 & 34 & 31.8 & 24 & 22.4 & 13 & 12.1 & 3.04 & 1.25 \\
\hline $\begin{array}{l}\text { 7. It bothers me } \\
\text { trying to } \\
\text { understand the } \\
\text { more complex } \\
\text { aspects of } \\
\text { English. }\end{array}$ & 18 & 16.8 & 35 & 32.7 & 32 & 29.9 & 18 & 16.8 & 4 & 3.7 & 3.42 & 1.07 \\
\hline $\begin{array}{l}\text { Total mean } \\
\text { score }\end{array}$ & & & & & & & & & & & 3.23 & 0.97 \\
\hline
\end{tabular}

$\mathrm{SA}=$ Strongly Agree; $\mathrm{A}=$ Agree; $\mathrm{N}=$ Neutral; $\mathrm{D}=$ Disagree; $\mathrm{SD}=$ Strongly Disagree; $\mathrm{Std}=$ Standard Deviation; $\mathrm{F}=$ Frequency; \%= Percent. 


\section{Learning English and using it in India}

Table 5 shows the subjects' attitudes towards learning English and practicing it in India. Item 8, "Learning English in India is good and enjoyable" was meant to show the attitude towards learning English in India, and awarded the response of neutral with a mean of 2.78 and standard deviation of 1.1.3. These results indicate that learning English in India is moderate. Besides examining the students' attitude towards learning English in India, item 9, "I can practice English anywhere in India" was meant to explore the students' attitude towards practicing English in India. Item 9 also elicited a neutral response with a mean score of 2.95 and standard deviation of 1.05. The subjects revealed that practicing English in India is moderate.

Table 5. The Descriptive Analysis of Learning English and Using it in India

\begin{tabular}{|c|c|c|c|c|c|c|c|c|c|c|c|c|}
\hline \multirow[t]{2}{*}{ Statement } & \multicolumn{2}{|l|}{ SA } & \multicolumn{2}{|l|}{$A$} & \multicolumn{2}{|l|}{$N$} & \multicolumn{2}{|l|}{ D } & \multicolumn{2}{|l|}{ SD } & \multirow[t]{2}{*}{ Mean } & \multirow{2}{*}{$\begin{array}{l}\text { St. } \\
\text { D }\end{array}$} \\
\hline & $\mathrm{F}$ & $\%$ & $\mathrm{~F}$ & $\%$ & $\mathrm{~F}$ & $\%$ & $\mathrm{~F}$ & $\%$ & $\mathrm{~F}$ & $\%$ & & \\
\hline $\begin{array}{l}\text { 8. Learning } \\
\text { English in India } \\
\text { is good and } \\
\text { enjoyable. }\end{array}$ & 6 & 5.6 & 25 & 23.4 & 31 & 29.0 & 29 & 27.1 & 16 & 15.0 & 2.78 & 1.13 \\
\hline $\begin{array}{l}\text { 9. I can practice } \\
\text { English } \\
\text { anywhere in } \\
\text { India. }\end{array}$ & 13 & 12.1 & 29 & 27.1 & 18 & 16.8 & 34 & 31.8 & 13 & 12.1 & 2.95 & 1.25 \\
\hline $\begin{array}{l}\text { Total mean } \\
\text { score }\end{array}$ & & & & & & & & & & & 2.86 & 1.05 \\
\hline
\end{tabular}

$\mathrm{SA}=$ Strongly Agree; $\mathrm{A}=$ Agree; $\mathrm{N}=$ Neutral; $\mathrm{D}=$ Disagree; $\mathrm{SD}=$ Strongly Disagree; $\mathrm{Std}$. = Standard Deviation; $\mathrm{F}=$ Frequency; \%= Percent.

\section{Types of Motivation}

\section{Instrumental Motivation}

Table 6 demonstrates the goals that motivate students to learn English. As stated earlier, Instrumental motivation towards learning English refers to utilitarian purposes or goals. Students reported that they learn English for the following goals:

1. To get a job.

2. To use English for future career.

3. To be a knowledgeable person.

4. For prestige.

5. For education purpose. 
The results in table 6 show that students have high instrumental motivation towards learning English. The highest mean score was given to item 7, "I learn English diligently because it is a medium of instruction in the university" with a mean score of 4.62 and standard deviation of 0.74 . And the lowest mean score was given to item 4, "If I know English well, others will respect me more" with a mean of 3.76 and standard deviation of 1.14 . The total mean score is 4.40 , with a standard deviation of 0.70 . The mean score of 4.40 indicates the response of strong agreement. Accordingly, the instrumental motivation towards learning English is high among Yemeni students in India. These results are in harmony with Zughoul (2003). He stated that English is needed in the Arab world for some purposes such as communication, education, and technology purposes. It is also a prerequisite for jobs, especially in the private sector.

Table 6. The Descriptive Analysis of Instrumental Motivation 


\begin{tabular}{|c|c|c|c|c|c|c|c|c|c|c|c|c|}
\hline \multirow[t]{2}{*}{ Statement } & \multicolumn{2}{|l|}{ SA } & \multicolumn{2}{|l|}{$A$} & \multicolumn{2}{|l|}{$\mathrm{N}$} & \multicolumn{2}{|l|}{ D } & \multicolumn{2}{|c|}{ SD } & \multirow[t]{2}{*}{ Mean } & \multirow[t]{2}{*}{ Std. } \\
\hline & $\mathrm{F}$ & $\%$ & $\mathrm{~F}$ & $\%$ & $\mathrm{~F}$ & $\%$ & $\mathrm{~F}$ & $\%$ & $\mathrm{~F}$ & $\%$ & & \\
\hline $\begin{array}{l}\text { 1. Learning English } \\
\text { is important for me } \\
\text { because it helps } \\
\text { me get a suitable } \\
\text { job in the future. }\end{array}$ & 64 & 59.8 & 32 & 29.9 & 6 & 5.6 & 1 & 0.9 & 4 & 3.7 & 4.41 & 0.93 \\
\hline $\begin{array}{l}\text { 2. Learning English } \\
\text { is important for me } \\
\text { because I will need } \\
\text { it for my future } \\
\text { career. }\end{array}$ & 76 & 71 & 21 & 19.6 & 6 & 5.6 & 2 & 1.9 & 2 & 1.9 & 4.56 & 0.83 \\
\hline $\begin{array}{l}\text { 3. Learning English } \\
\text { is important for me } \\
\text { because it makes } \\
\text { me a more } \\
\text { knowledgeable } \\
\text { person. }\end{array}$ & 68 & 63.6 & 29 & 27.1 & 6 & 5.6 & 2 & 1.9 & 2 & 1.9 & 4.49 & 0.83 \\
\hline $\begin{array}{l}\text { 4. If I know English } \\
\text { well, others will } \\
\text { respect me more. }\end{array}$ & 32 & 29.9 & 38 & 35.5 & 22 & 20.6 & 9 & 8.4 & 6 & 5.6 & 3.76 & 1.14 \\
\hline $\begin{array}{l}\text { 5. Learning English } \\
\text { is essential for me } \\
\text { because it helps } \\
\text { me search for } \\
\text { information and } \\
\text { English materials } \\
\text { on the Internet. }\end{array}$ & 77 & 72 & 22 & 20.6 & 4 & 3.7 & 3 & 2.8 & 1 & 0.9 & 4.60 & 0.77 \\
\hline $\begin{array}{l}\text { 7. I learn English } \\
\text { diligently because } \\
\text { it is a medium of } \\
\text { instruction in the } \\
\text { university. }\end{array}$ & 61 & 57 & 35 & 32.7 & 5 & 4.7 & 3 & 2.8 & 3 & 2.8 & 4.62 & 0.74 \\
\hline Total mean score & & & & & & & & & & & 4.40 & 0.70 \\
\hline
\end{tabular}

$\mathrm{SA}=$ Strongly Agree; $\mathrm{A}=$ Agree; $\mathrm{N}=$ Neutral; $\mathrm{D}=$ Disagree; $\mathrm{SD}=$ Strongly Disagree; $\mathrm{Std}$. = Standard Deviation; $\mathrm{F}=$ Frequency; \%= Percent.

\section{Integrative Motivation}

The results in table 7 show that Yemeni students have high integrative motivation towards learning English. The highest average was given to item 6, "Learning English helps me read English books, articles, newspapers, and magazines" with a mean score of 4.52 and standard deviation of 0.78 , followed by item 4, "Learning English helps me understand American and British movies and talk-shows" with a mean score of 4.48 and standard deviation of 0.94 . The lowest average was awarded to item 3 , "Learning English helps me learn about the values and beliefs of English native speakers" with a mean score of 
4.18 and standard deviation of 0.90 . The total mean score for integrative motivation is 4.37 , which indicates the response of strong agreement. Accordingly, Yemeni students have high integrative motivation towards learning English. These results support Zughoul's claim (2003) that the influence of American cultures and ways of living are remarkable among Arabians in urban centers. Most Yemeni students in India belong to urban areas in Yemen or are affected by urban life. Therefore, they have high integrative motivation towards learning English.

The results of this study are similar to (Qashoa, 2006; Yvonne, 2009; Degang, 2010; Alshamy, 2012; Köseoğlu, 2013; Goktepe, 2014; Hashemi \& Hadavi, 2014). They found that students have instrumental and integrative motivation towards learning English. Moreover, the findings of this study revealed that students are highly motivated instrumentally and integratively towards learning English. The mean score of instrumental motivation is 4.40 , and integrative motivation is 4.37 . These scores indicate that the level of instrumental and integrative motivation is the same. Therefore, this study's results contradict (Qashoa, 2006); Al-Tamimi \& Shuib, 2009; Yvonne, 2009; Al-Khasawneh \& Al-Omari, 2015) where they found that the instrumental motivation is higher than the integrative motivation. This study's findings also contradict (Degang, 2010; Alshamy, 2012), where they found that integrative motivation is higher than instrumental motivation.

The findings showed that Yemeni students in India have high instrumental and integrative motivation towards learning English. Therefore, the English language should be taught intensively in Yemen, whether in schools or universities. As the English language is taught only from grade 7 in public schools and level one in university education, it should be taught from grade one in schools, and it should be a compulsory subject from level 1-4 in Yemeni universities. This will help students improve their English language to function effectively in their education or occupation, whether in Yemen or abroad.

\section{Table 7. The Descriptive Analysis of Integrative Motivation}




\begin{tabular}{|c|c|c|c|c|c|c|c|c|c|c|c|c|}
\hline \multirow[t]{2}{*}{ Statement } & \multicolumn{2}{|l|}{ SA } & \multicolumn{2}{|l|}{$A$} & \multicolumn{2}{|l|}{$\mathrm{N}$} & \multicolumn{2}{|l|}{ D } & \multicolumn{2}{|c|}{ SD } & \multirow[t]{2}{*}{ Mean } & \multirow[t]{2}{*}{ Std. } \\
\hline & $\mathrm{F}$ & $\%$ & $\mathrm{~F}$ & $\%$ & $\mathrm{~F}$ & $\%$ & $\mathrm{~F}$ & $\%$ & $\mathrm{~F}$ & $\%$ & & \\
\hline $\begin{array}{l}\text { 1. Learning English } \\
\text { helps me } \\
\text { understand the } \\
\text { cultures and } \\
\text { traditions of native } \\
\text { English speakers. }\end{array}$ & 62 & 57.9 & 35 & 32.7 & 5 & 4.7 & 4 & 3.7 & 1 & 0.9 & 4.43 & 0.82 \\
\hline $\begin{array}{l}\text { 2. Learning English } \\
\text { helps me make } \\
\text { friends easily with } \\
\text { foreigners. }\end{array}$ & 60 & 56.1 & 28 & 26.2 & 13 & 12.1 & 3 & 2.8 & 3 & 2.8 & 4.30 & 0.98 \\
\hline $\begin{array}{l}\text { 3. Learning English } \\
\text { helps me learn } \\
\text { about the values } \\
\text { and beliefs of } \\
\text { English native } \\
\text { speakers. }\end{array}$ & 46 & 43 & 41 & 38.3 & 15 & 14 & 3 & 2.8 & 2 & 1.9 & 4.18 & 0.90 \\
\hline $\begin{array}{l}\text { 4. Learning English } \\
\text { helps me } \\
\text { understand } \\
\text { American and } \\
\text { British movies and } \\
\text { talk-shows. }\end{array}$ & 64 & 59.8 & 34 & 31.8 & 6 & 5.6 & 2 & 1.9 & 1 & 0.9 & 4.48 & 0.76 \\
\hline $\begin{array}{l}\text { 5. Learning English } \\
\text { enables me to } \\
\text { communicate with } \\
\text { different people. }\end{array}$ & 58 & 54.2 & 36 & 33.6 & 6 & 5.6 & 4 & 3.7 & 3 & 2.8 & 4.33 & 0.94 \\
\hline $\begin{array}{l}\text { 6. Learning English } \\
\text { helps me read } \\
\text { English books, } \\
\text { articles, } \\
\text { newspapers, and } \\
\text { magazines. }\end{array}$ & 69 & 64.5 & 30 & 28 & 4 & 3.7 & 3 & 2.8 & 1 & 0.9 & 4.52 & 0.78 \\
\hline Total mean score & & & & & & & & & & & 4.37 & 0.70 \\
\hline
\end{tabular}

$\mathrm{SA}=$ Strongly Agree; $\mathrm{A}=$ Agree; $\mathrm{N}=$ Neutral; $\mathrm{D}=$ Disagree; $\mathrm{SD}=$ Strongly Disagree; Std. = Standard Deviation; $\mathrm{F}=$ Frequency; \%= Percent.

\section{Inferential Analysis}

An inferential analysis test is used to identify the significant differences between students according to their education level and gender. The independent $t$-test is used to address the following questions:

1. Are there any differences in the attitudes of students according to their gender and education level? 
2. Are there any differences between the students' motivation according to their gender and educational level?

3. Are there any differences in the students' anxiety of English according to their gender and education level?

4. Are there any differences in the attitudes of Yemeni students towards learning English and practicing it in India?

Table 8. Means, Standard deviations, and P-values according to the students' education level and gender.

\begin{tabular}{|c|c|c|c|c|c|c|c|c|c|c|}
\hline \multirow[t]{2}{*}{ Variable } & \multicolumn{5}{|c|}{ Education Level } & \multicolumn{5}{|c|}{ Gender } \\
\hline & \multicolumn{2}{|c|}{$\begin{array}{l}\text { Postgraduate } \\
\mathrm{N}=74\end{array}$} & \multicolumn{3}{|c|}{$\begin{array}{l}\text { Undergraduate } \\
\mathrm{N}=33\end{array}$} & \multicolumn{2}{|c|}{ Male $n=92$} & \multicolumn{3}{|c|}{ Female $\mathrm{N}=15$} \\
\hline \multirow[t]{2}{*}{ Attitude } & Mean & Std. & Mean & Std. & $\begin{array}{l}\text { P- } \\
\text { value }\end{array}$ & Mean & Std. & Mean & Std. & $\begin{array}{l}\text { P- } \\
\text { value }\end{array}$ \\
\hline & 4.67 & 0.49 & 4.38 & 1.00 & $0.04 *$ & 4.59 & 0.65 & 4.53 & 0.97 & 0.78 \\
\hline $\begin{array}{l}\text { Anxious of } \\
\text { English } \\
\text { learning }\end{array}$ & 3.19 & 1.00 & 3.32 & 0.89 & 0.53 & 3.18 & 1.00 & 3.53 & 0.74 & 0.193 \\
\hline $\begin{array}{l}\text { Learning } \\
\text { English and } \\
\text { use it in India }\end{array}$ & 2.87 & 0.96 & 2.85 & 1.22 & 0.91 & 2.83 & 1.05 & 3.07 & 1.05 & 0.42 \\
\hline Instrumental & 4.43 & 0.55 & 4.33 & 0.96 & 0.47 & 4.43 & 0.66 & 4.25 & 0.90 & 0.36 \\
\hline Integrative & 4.42 & 0.58 & 4.26 & 0.93 & 0.26 & 4.38 & 0.68 & 4.31 & 0.88 & 0.72 \\
\hline
\end{tabular}

The results in table 8 reveal the significant differences between (postgraduate and undergraduate students) and between (males and females). The results are as follows:

- The results reveal that there is a significant difference in the attitude of postgraduate and undergraduate students towards learning English. The mean postgraduate score is 4.67, and the undergraduate score is 4.38 with P-value of 0.04 . This indicates a significant difference between these two groups, and the difference favors postgraduate students. The results show that postgraduate students have a higher positive attitude towards learning English than undergraduate students.

- There is no significant difference between males and females regarding the attitude towards learning English. The mean scores of males and females are 4.59 and 4.53, respectively, with a P-value of 0.78 (P-value is above 0.05$)$. These results support Al-Sohbani (2015) that there is no significant 
difference between males and females and contradict Gajalakshmi (2013) where he found that males have a higher attitude than females.

- There is no significant difference in the students' English anxiety according to their education level and gender, where the P-value is 0.53 for education level and 0.19 for gender. The $p$-value is above 0.05 , so there is no significant difference between students.

- The results show no significant difference in the students' attitude towards learning English and using it in India according to the students' education level and gender, where the P-value is 0.91 and 0.42 , respectively.

- There is no significant difference between postgraduate and undergraduate students regarding their instrumental motivation towards learning English. The mean instrumental scores of postgraduate and undergraduate students are 4.43 and 4.33 , respectively. The P-value is 0.047 (it is above 0.05 level).

- The results reveal no significant difference between postgraduate and undergraduate students regarding their integrative motivation towards learning English. The mean integrative scores of postgraduate and undergraduate students are 4.42 and 4.26 , respectively. The P-value is 0.26 , so this indicates that there is no significant difference where P-value is above 0.05 level.

- There is no significant difference between male and female students regarding instrumental and integrative motivation, where P-value is 0.36 and 0.72 . The P-value is above 0.05 . These results contradict (Alshamy 2012; Al-Khasawneh and Al-Omari, 2015) where they found that females have a higher motivation than males.

According to the results interpreted above, postgraduate students have a higher positive attitude towards learning English than undergraduate students. Postgraduate students have a great experience about the importance of learning English, where they use it more than undergraduate students. This is compatible with Oskamp \& Schultz (2005) where they argued that the experience about an object leads a person to have an attitude towards that object. Oskamp \& Schultz claimed that the formation of attitude towards an object as favorable or unfavorable refers to an early experience about that object.

\section{Conclusion}

This study focused on the attitudes and motivation of Yemeni students in India towards learning English. It tries to determine whether Yemeni students have a positive or negative attitude towards learning English and the types of motivations that students have. Two types of motivation were investigated in the current study: instrumental and integrative motivation. The field of this study was the postgraduate and undergraduate students in different states all over India. The descriptive results revealed that Yemeni students have a high positive attitude towards learning English. They were motivated instrumentally and integratively towards learning English. Regarding the anxiety of the English language, the results showed that the students' anxiety was moderate. Moreover, the results revealed that learning English and using it in India is moderate (i.e., not Excellent, but not bad). The results gathered from the independent t-test showed that there is a significant difference in the postgraduate and undergraduate students' attitudes 
towards learning English, where Postgraduate students have a higher positive attitude than undergraduate students. The results also showed no significant differences in the subjects' instrumental and integrative motivation towards learning English. Besides, there is no significant difference between male and female students regarding their attitudes and motivation towards learning English. Eventually, the present research recommends studying the students' attitudes and motivation in Yemen towards learning English. Another study should include another factors and carry out on different subjects in Yemen.

\section{Declarations}

1. Availability of data and materials: All the required materials such as piloting study, main questionnaire, Excel of responses, and SPSS data and variables are available. Piloting study and main questionnaire are saved in the researchers' Google derive. Data analysis is saved in SPSS version 20.

2. Competing interests: The manuscript complied with ethical standards. No conflict of interest. It agreed to research ethics.

3. Funding (optional): There is no funding for such research received. Funding information is not applicable.

\section{Authors' contributions}

- The corresponding author of this study did the introduction, methodology, interpretation of data analysis, conclusion and cited the references.

- The second author collected the data and did the instruments validity, revision and proofreading of the manuscript.

- Third author did the analysis of data using SPSS version 20.

They all read and approved the final manuscript. We all agreed to publish the manuscript in Asian-Pacific Journal of Second and Foreign Language Education.

Acknowledgements: Not applicable

\section{References}

1. Abidin, M. J. Z., Pour-Mohammadi, M., \& Alzwari, H. (2012). EFL students' attitudes towards learning the English language: The case of Libyan secondary school students. Asian Social Science, 8(2), 119.

2. Al Noursi, O. (2013). Attitude towards learning English: The case of the UAE technological high school. International Research Journals, Educational Research 4(1), 21-30.

3. Al-Anisi, M.H. (2016). The attitudes of learners and teachers toward learning and teaching English at Al-Baida'a city schools. An International Journal in English, 2 (3). 
4. Alkaabi, A. (2016). Saudi students' motivation and attitudes toward learning English as a second language and their willingness to invest in learning it (Master's thesis). Cloud State University, Minnesota, United States.

5. Al-Khasawneh, F. M., \& Al-Omari, M. A. (2015). Motivations towards learning English: The case of gifted Jordanian students. International Journal of Education, 7(2), 306-321.

6. Almamun, S. A., Rahman, A. R. M. M., Rahman, A. R. M. M., \& Hossain, M. A. (2012). Students' attitudes towards English: The case of life science school of Khulna University. International Review of Social Sciences and Humanities, 3 (1), 200-209.

7. Alshamy, A.A.M. (2012). Attitudes and motivation of EFL learners towards English: A Case study of PYP Saudi University students (Master's thesis). University of Sunderland, United Kingdom.

8. Al-Sohbani, Y.A.Y. (2015). The role of attitudes and motivation in learning English as a foreign language among Yemeni rural secondary school students. Journal of Teaching and Teacher Education, 3 (1).

9. Al-Tamimi, A., \& Shuib, M. (2009). Motivation and attitudes towards learning English: A study of petroleum engineering undergraduates at Hadhramout University of sciences and technology. GEMA Online Journal of Language Studies, 9(2).

10. Al-Zubeiry, H. Y. A. The Socio-psychological Orientations of Saudi Learners of English as a Foreign.Umm Al-Qura University Journal \& of languages \& literature, (8).

11. Astrid, A., Desvitasari, D., \& Aqdam, A. (2020). The language attitude towards English learning among EFL learners: a case at one private Islamic Senior High School. Ta'dib: Jurnal Pendidikan Islam, 25(1), 32-43.

12. Bartram, B. (2010). Attitudes to modern foreign language learning: insights from comparative education. Continuum International Publishing Group.

13. Bohner, G., \& Dickel, N. (2010). Attitudes and attitude change. Department of Psychology, University of Bielefeld, D-33501 Bielefeld, Germany. Annual Reviews.

14. Briñol, P., \& Petty, R.E. (2012). The history of attitudes and persuasion research. In A. Kruglanski \& W. Stroebe (Eds.). Handbook of the history of social psychology (PP. 285-320). New York: Psychology Press.

15. Chalak, A., \& Kassaian, Z. (2010). Motivation and attitudes of Iranian undergraduate EFL students towards learning English. GEMA Online ${ }^{\circledR}$ Journal of Language Studies, 10(2).

16. Degang, M. (2010). Motivation toward English language learning of the second-year Thai undergraduate students majoring in business English at an English medium university (Master's Dissertation). Srinakharinwirot University, Bangkok, Thailand.

17. Gajalakshmi. (2013). High school students' attitude towards learning the English language. International Journal of Scientific and Research Publications, 3(9), 1-7. Retrieved from http://www.ijsrp.org/research-paper-0913.php?rp=P211739.

18. Gardner, R. C. (1985). Social psychology and second language learning. London. Edward Arnold publishers Itd. 
19. Gardner, R. C. (2006). The socio-educational model of Second Language Acquisition: A research paradigm. EUROSLA Yearbook, 6, 237-260. doi:10.1075/eurosla.6.14gar

20. Goktepe, F. T. (2014). Attitudes and motivation of Turkish undergraduate EFL students towards learning the English language. Studies in English Language Teaching, 2(3), 314.

21. Harrell, K. D. (2000). Attitude is everything. 10 Life-Changing Steps to Turning Attitude into Action. Harper Collins.

22. Hashemi, Z., \& Hadavi, M. (2014). Exploring the roles of integrative and instrumental motivation on English language acquisition among Iranian medical and dentistry students. International Journal of Language and Linguistics, 2(5-1), 18-23. Doi: 10.11648/ j.jill.s.2014020501.13.

23. Holbah, W.A. (2015). Motivation for learning English in the Saudi Arabian context: Perceptions of learners, teachers, and parents (Doctoral dissertation). Flinders University, Adelaide.

24. Isti, M., \& Istikharoh, L. (2019). EFL students' attitude toward learning English. Journal of Sains Social dan Humaniora, 3(2), 95-105.

25. Köseoğlu, Y. (2013). Motivational orientations for learning English: The case of Turkish University students. Journal of Emerging Trends in Educational Research and Policy Studies (JETERAPS) 4(5), 800-806.

26. Krashen, S., D. (1981). Second language acquisition and second language learning. Pergamon Press Inc. University of Southern California.

27. Oskamp, S., \& Schultz, W. (2005). Attitudes and opinions ( $3^{\text {rd }}$ ed). Mahwah, New Jersey, London. Lawrence Erlbaum Associates, Inc., Publishers.

28. Pineda, S.A. (2011). Attitude, motivation, and English language learning in a Mexican college context (Doctoral Dissertation). The University of Arizona.

29. Qashoa, S.H.H. (2006). Motivation among English learners in the secondary schools on the Eastern coast of the UAE (Master's thesis). British university, Dubai.

30. Segran, M.G. (2015). Role of integrative and instrumental motivation in the L2 learning of local Malaysian ESL university students. Help University.

31. Singh, H.K. (2014). Attitudes towards English language learning and language use among secondary school students (Master's thesis). University of Malaya, Kuala Lumpur, Malaysia.

32. Yvonne, Y.S.M. (2009). Motivation for English language learning: a study of Hong Kong vocational students (Doctoral dissertation). University of Leicester, United Kingdom.

33. Zughoul, M. (2003). Globalization and EFL/ESL pedagogy in the Arab world. Journal of Language \& Learning, 1 (2), 106-146.

34. Kothari, C. R. (2004). Research methodology: Methods and Techniques. Ansari Road, Daryaganj, New Delhi. New Age International (P) Limited, Publishers.

\section{Supplementary Files}


This is a list of supplementary files associated with this preprint. Click to download.

- Appendices.doc 